UNIVERSITY OF CHITRAL JOURNAL OF LINGUISTICS AND LITERATURE

VOL. 4 | ISSUE II | JULY - DEC | 2020

ISSN (E): 2663-1512, ISSN (P): 2617-3611

\title{
Employability of Persuasive and Rhetorical Strategies: A Corpus-Assisted Crititacal Discourse Analysis of Prime Minister Imran Khan's Selected Address
}

\author{
Naeema Shah \\ M. Phil Scholar, Sardar Bahadur Khan Women University, Balochistan \\ anzalnashah@gmail.com
}

\begin{abstract}
This study deals with the utilization of Persuasive and Rhetorical Strategies used by Prime Minister Imran Khan in his address to the nation on $17^{\text {th }}$ March, 2020. This address was made in the background of Covid-19 pandemic. Aristotle's concept of persuasive components namely ethos, pathos, and logoswas followed to examine the utilization of these devices. Furthermore, rhetorical devices like rhetorical questions, inclusiveness and exclusiveness were also analyzed. Mixed Method approach was used to analyze the data. Quantitative data was obtained by using Corpus software AntConc, 3.5.8 (windows) 2019. Concordances were taken through this software, related to different devices and techniques. This numerical data was elaborated qualitatively. On the basis of the findings of the study, it can be said that PM Imran Khan practiced these techniques effectively and extensively.
\end{abstract}

Keywords: Persuasive, Rhetorical, Ethos, Pathos, Logos, Corpus

\section{Introduction}

On March $17^{\text {th }}$, Imran Khan, the prime minister of Pakistan addressed the nation in the backdrop of the Covid 19 Pandemic. Corona Virus was discovered in Wuhan, China, in December 2019. It started spreading rapidly worldwide. Seeing this rapid outbreak all over the world, The World Health Organization (WHO) declared this infection a Public Health Emergency of International concern on January 30, 2020. On March $11^{\text {th }}$, 2020, it was declared an international pandemic. The first case of corona virus came to Pakistan on $26^{\text {th }}$ February, 2020. Till $11^{\text {th }}$ March, confirmed corona cases in Pakistan reached the figure 20. On $13^{\text {th }}$ March, National Security Council met with the prime minister and decided to close all the schools, colleges and universities in the country in the wake of threat of spreading Covid-19 rapidly. Later on, the government took 
precautionary measures and banned all the public gatherings and business activities i.e. sports, shopping malls, marriage halls, markets, etc. In other words, life came to a standstill.

Pakistan is a developing country which cannot bear the burden of such restrictions. About $45 \%$ population of Pakistan live below the poverty line. Almost seven to eight million are daily wagers in the country who live upon and support their families with their daily income. In such economic conditions, there is always possibility of panic creation among the masses which may lead to chaos in the society. In order to make the public aware of the severity of corona virus, steps taken by the government and to soothe the frustration and depression of the people, the prime minister addressed the nation in this time of crisis. Prime minister is the head of the government and the whole nation looks towards him in the time of trial. He has to lead from the front and head different organizations. He should have the qualities of persuasion and rhetoric to convince and motivate the masses. Empirical studies are often used to analyze organizational speeches (Redding, 1985). Recently, rhetorical aspect of speech in organization has become the subject of research (Putnam and Cheney, 1985). The present study also focuses on the rhetorical and persuasive techniques adopted by PM Imran khan in his address to the nation. Classical Greek and Roman philosophers founded the basic concepts and theories related to present rhetorical theory (Golden, Berquist, and Coleman, 1983).

Rhetorical and persuasive devices are the hallmark of an impressive public speaker (Baig et al., 2019, p. 252). Identity and ideology are constructed through language (Aazam et al., 2019,p. 162), so, the use of language becomes more important for political leaders to convince the people (Kennedy, 2007 p. 1). Language is a system of coding and decoding symbols and words (Baig et al., 2020, p. 230). All the great leaders around the world use persuasive tools of language to convey their ideas in an effective manner. Being the prime minister of a big country, Imran Khan's speeches and addresses have their impact not only in the country but also outside, having persuasive and rhetorical qualities. This research analyzes the utilization of such tools in his address to the nation after the outbreak of Corona pandemic. The political leader passes on true and sensible information to the public in order to seek their consent in decision making (Johnson \& Jonson, 2000 p. 1). 
Political leaders play with words to inspire and satisfy the audience. Words are rich in social, political, racial and economical ideologies (Khalil et al., 2017). Various secret ideologies and policies are propagated through language. Critical Discourse Analysis is used to expose such hidden aspects of language.

Discourse can be defined as the text (spoken or written) and the context ( the situation in which language is produced) to communicate (Van Dijk's, 1977 p. 45). Language should be wellformed but not necessarily grammatical (Cook, 1992). Language and society are part and parcel and language is used as a social practice (Fairclough, 1996, p. 72)

It means that discourse cannot be impartial as it functions to establish political, religious, racial and cultural ideologies (Atkins, 2002). Text that can be analyzed statistically has been considered under the general idea of discourse for this research (Titscher et al.).

Discourse, power and ideology are inter-connected. Political leaders try to gain power through politics in order to put certain social, political and economic ideologies into practice. Political leaders and rulers may implement their ideas by force but they use rhetorical and persuasive tactics to motivate people to follow them (Jalilifar \& Alavi, 2011).

Rhetoric includes many persuasive techniques. In other words, rhetoric is a tool to convince people by exploiting language (Kennedy, 2007). Discourse is a medium of understanding each other's actions (Aazam et al., 2019, p. 192). In this study, the researcher examines the utilization of various rhetorical and persuasive techniques by PM Imran Khan in his address to the nation after the outbreak of Corona Virus in Pakistan.

\section{Rationale of the Study}

The researcher has selected PM Imran Khan's address to the nation after the declaration of emergency in the country in the backdrop of Covid 19. It was a time of panic and frustration for the nation. In such a crisis, the nation looks to the government specially its head to take some solid measures to lessen the gravity of the situation. So, it is quite suitable to examine the existence of persuasive and rhetorical tools in the address under discussion. This study will also highlight the point how a leader manipulates language in such conditions.

\section{Objectives}

- $\quad$ To examine the various persuasive devices utilized by PM Imran Khan in his address to the nation. 
UNIVERSITY OF CHITRAL JOURNAL OF LINGUISTICS AND LITERATURE

VOL. 4 | ISSUE II | JULY - DEC | 2020

ISSN (E): 2663-1512, ISSN (P): 2617-3611

- $\quad$ To find out the use of rhetorical techniques in PM Imran Khan's address to the nation.

\section{Questions}

1. How does Prime Minister Imran Khan utilize various persuasive devices?

2. What are the rhetorical techniques used by PM Imran Khan in his address to the nation?

\section{Significance of the Study}

In spite of some detailed and statistical researches on discourse in relation to power and ideology, a leader's use of rhetorical and persuasive techniques has often been ignored (Conger, 1991, 1999). No doubt, most of the researches that have analyzed the link between leadership and discourse critically, set aside the connection between discourse and manipulation of rhetorical and persuasive tools by the leaders (e.g., Beasley, 2004; Bligh \& Hess, 2007; Bligh, Kohles, \& Meindl, 2004; Shamir et al., 1994).

\section{Delimitation}

The researcher has selected only one address of Prime Minister IMran Khan to the nation because it is a recent phenomenon and the English version of the above mentioned address could not be found from any source as it was in Urdu. The researcher himself had to download, translate and transcribe it into English. So, due to time constraints, only one address could be possible to analyze.

\section{Literature Review}

Persuasion is the basic quality of any public address because it involves the whole nation in which all the sections of the society have to be convinced and satisfied. Persuasive strategies are followed to mould the ideas of the people regarding a particular public issue (Nelson,2004). In order to be argumentative and logical, the leader should be well versed in persuasive strategies. While addressing the nation, it is imperative for the leader to have full mastery of rhetorical tools.

Rhetorically competent leader gives shape to social realities and establish meaning through their communication ( Smircich \& Morgan, 1982). Social realities of the followers are shaped by the leaders through the use of rhetorical tactics (Conger, 1991). A charismatic leader influences, motivates and stimulates the masses intellectually (Bass, 1996). A leader should be competent in 
the use of rhetoric as it is a key feature of leadership (Bitzer, 1968) as it directly influences the masses (Abrahamson, 1997). It directly affects the management and the responses of the concerned stekeholders (Campbell, Follender, \& Shane, 1998). The use of rhetorical strategies helps the leader specially the head of the government accomplishing the policy objectives of the state (Sillince, 2006). When the leaders do not use rhetoric as a technique, they simply refer to empty words in the given situation (e.g., Cooney \& Sewell, 2008). Linguistic scholars consider rhetoric as a means to control and manipulate others through various devices as a set of different tools ( pathos, ethos and logos).

Persuasion can be defined as the skill of manipulating language in a way that the listener willingly becomes ready to act according to the addresser's intentions (Simons, 1976 as cited in Alghamdi \& Rand, 2019). Rhetoric was first defined by Corax and Tisias as the "artificer of persuasion" (Lin, 2000). Aristotle considered rhetoric as the most effective tool of persuasion. Burke defines rhetoric as the "use of words by human agents to form attitudes or to induce actions in other agents" (Lin, 2000). According to these definitions, salient features of rhetoric can be listed below: 1) rhetoric is the skil to use language; 2) the purpose of rhetoric is to persuade the addressees; 3) rhetorical language is used to mould or shape other's actions and conducts. Therefore, rhetoric creates a channel through which language systematically affects the thinking and actions of others. Speakers manipulate language to alter reality by force i.e. physical reality is guided by the use of language (Berger, 1969). The addresser can change the people's expectations, liking or disliking and their behaviors towards a specific issue by using symbols, language, power relations and reason (Peng, 2007). Therefore, rhetoric is intentionally utilized for the sake of persuasive communication (Higgins \& Walker, 2012).

Aristotle emphasizes on three important components to have impressive persuasion:

1. Ethos: the character of the addresser,

2. Pathos: the sentiments or emotions of the addressee,

3. Logos: the reasoning of the addresser's arguments (Beiner, 1983, as cited in Triadafilopoulos, 1999). Audience easily buys the views of the leader/addresser and change their thinking if he follows the above mentioned elements of persuasion (Aristotle, 1984). In order to achieve a persuasive speech or discourse, the speaker should exhibit his 
UNIVERSITY OF CHITRAL JOURNAL OF LINGUISTICS AND LITERATURE

VOL. 4 | ISSUE II | JULY - DEC | 2020

or her own character, inspire the people emotionally and mention facts and figures that appeal to the natural instinct of the audience.

\section{Ethos}

It is a moral appeal by the speaker that he or she offers himself or herself as credible and trustworthy. Ethos stresses the character of the addresser $\backslash$ speaker by intentionally displaying his or her image in such a manner that makes the addressees believe that the addresser $\backslash$ speaker is honest, able and dependable.

\section{Logos}

It is an intellectual appeal that emphasizes reason and logic. It means that the arguments of the addresser should be supported by facts and figures in order to be clear and acceptable to the people (Higgins \& Walker, 2012, p. 198).

\section{Pathos}

The speaker invokes the emotions of the audience (e.g. pleasure, optimism, pessimism, sorrow, pain, fear, sadness, etc). According to Aristotle (1984), "the emotions are all those feelings that so change men as to affect their judgments and that are also attended by pain or pleasure. Such are anger, pity, fear, and the like, with their opposites" (pp. 91-92). Hope, happiness, pleasure and optimism are positive feelings that can be made logical with the help of other motivational arguments (Erisen \& Villalobos, 2014).

The speaker uses persuasive and rhetorical techniques to bring others around with his arguments, to make his ideas and outcomes acceptable and follow his thoughts. He adopts different strategies to convince others. Some of more common techniques are:

1. Appeal: one of the persuasive devices is to appeal to the emotions, fears, wishes of the people such as wish to protect life, property and honor, family; to be acceptable, to be loved, to be distinguished, to be rich, to be proud of one's faith, religion, etc.

2. Evidence: The use of evidence makes the speaker well-informed in the eyes of the listeners and his argument becomes credible and reasonable for them.

3. Attacks: Sometimes, the addresser or the speaker attacks the opponent ideas or people to be mean, cheat, harmful and destructive. He also makes fun of such ideas to persuade the audience. 
4. Use of Inclusive and Exclusive words: Inclusive words such as the use of first person pronouns; we,our us, and the exclusive words : "they" create a feeling of unity and a realization of responsibility among the audience.

5. Cause and Effect: A good speaker creates a cause and effect relationship for any issue or phenomenon to make the listeners think about other factors involved or attached with it.

6. Connotations: A persuasive speaker attaches emotional meanings with the words to fulfill their purpose e.g. 'terrorist' vs 'freedom fighter'.

7. Analogy: Analogy is a type of argumentation in which the addresser draws a comparison between two things to highlight a specific point e.g., quarantines is like a prison and the quarantined people are like prisoners.

8. Generalizations: The speaker gives sweeping statements about the whole group on the basis of its two or three members, for example: all the members of the opposition are corrupt. It might be persuasive if the listeners consider it to be acceptable otherwise the situation can be vice versa.

9. Formal Language: The use of formal language by the speaker makes the speaker to have sound knowledge regarding the issue under consideration by excluding sentiments from the issue. This makes the argument logical and appropriate.

10. Colloquial Language: it means the use of simple, informal, everyday, conversational language that involves the ideas of the lower people and gives them the realization that the speaker is also one of them.

11. Repetition: the speaker repeats certain letters, words and phrases to make sure that his point of view is well understood and kept in mind by the audience.

12. Hyperbole: Sometimes, the speaker exaggerates a specific point to emphasize it. It is also used to ridicule the opponent's views.

13. Rhetorical Questions: Questions that are not asked to be answered but only for the confirmation of the opinion held by the speaker. They involve the listeners and motivate them to think over the problem and approve the speaker's answer. 
UNIVERSITY OF CHITRAL JOURNAL OF LINGUISTICS AND LITERATURE

VOL. 4 | ISSUE II | JULY - DEC | 2020

\section{Methodology and Theoretical Framework}

A corpus-assisted discourse (CAD) methodology was utilized for the analysis of Imran Khan's address to the nation., An authenticated analysis of discourse in context can be done with the help of corpus (Partington et al. 2013; Taylor 2014). CAD methodology helps the researcher to uncover existing styles in discourse along with the understanding of implicit intentions of the speaker behind his speech (Koteyko 2014). Both quantitative and qualitative approaches are applied for CAD analysis of a discourse (Siiner 2018). Analysis of speeches and addresses of political leaders is a major subject in Corpus Linguistics (Van Dijk, 1998). Various studies have applied this mixed corpus-based approach to analyze the speeches of politicians with the focus on different aspects of critical discourse analysis (Sharififar/Rahimi 2015).

When Imran Khan addresses the nation, he uses Urdu language as it is understandable for all the Pakistanis. The present study undertook one of his present addresses to the nation, downloaded it from YouTube and translated it into English, checked the mistakes of grammar on software "grammarly". Then, it was converted to txt form through online software for its suitability to Antconc software. This document comprises 2,162 tokens. The concordances of different key words were taken from AntConc 3.5 .8 (windows) 2019, software. Then, they were analyzed qualitatively in detail.

\section{Theoretical Framework}

This study followed the Aristotelian concept of persuasion. According to which, there are three elements of a good rhetoric: ethos (the character of the speaker), pathos ( appeal to the emotions of the listeners), logos ( logical arguments presented by the addresser) (Ko, 2015,p. 115). In the present scenario of Covid-19 pandemic, it becomes pertinent to seek whether a leader has the ability to convince and persuade his people or not. for the same reason, this theory was adopted to examine its utilization by Imran Khan in his address to the nation. The statistical data were obtained through the use of corpus software.

\section{Analysis}

\section{Ethos}

About two thousand years ago, Aristotle, the Greek philosopher opined that the audience could be persuaded through three channels: ethos, pathos, and logos. The speaker persuades his 


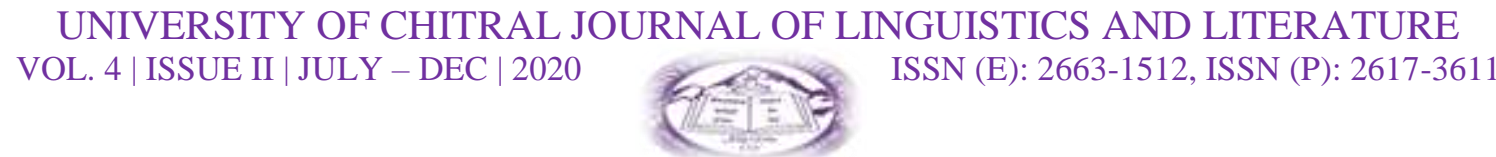

listeners on the basis of his high moral character accompanied by confidence. The speaker should gain this confidence through his speech not through prior image of the speaker's image (Aristotle, 1926, 17 in Cockcroft \& Cockcroft,2014, 6).

Aristotle's above mentioned views introduce ethos which means to persuade through character and self positioning. Self positioning is a set of ethics projected by the speaker or addresser through language and conduct. It is concerned with the speaker's image. The word "ethos" is derived from Greek words "custom", "habit", or "character". Anyhow, the word "ethos" is about our ethics or ethical norms.

\section{Use of Personal Pronoun "I"}

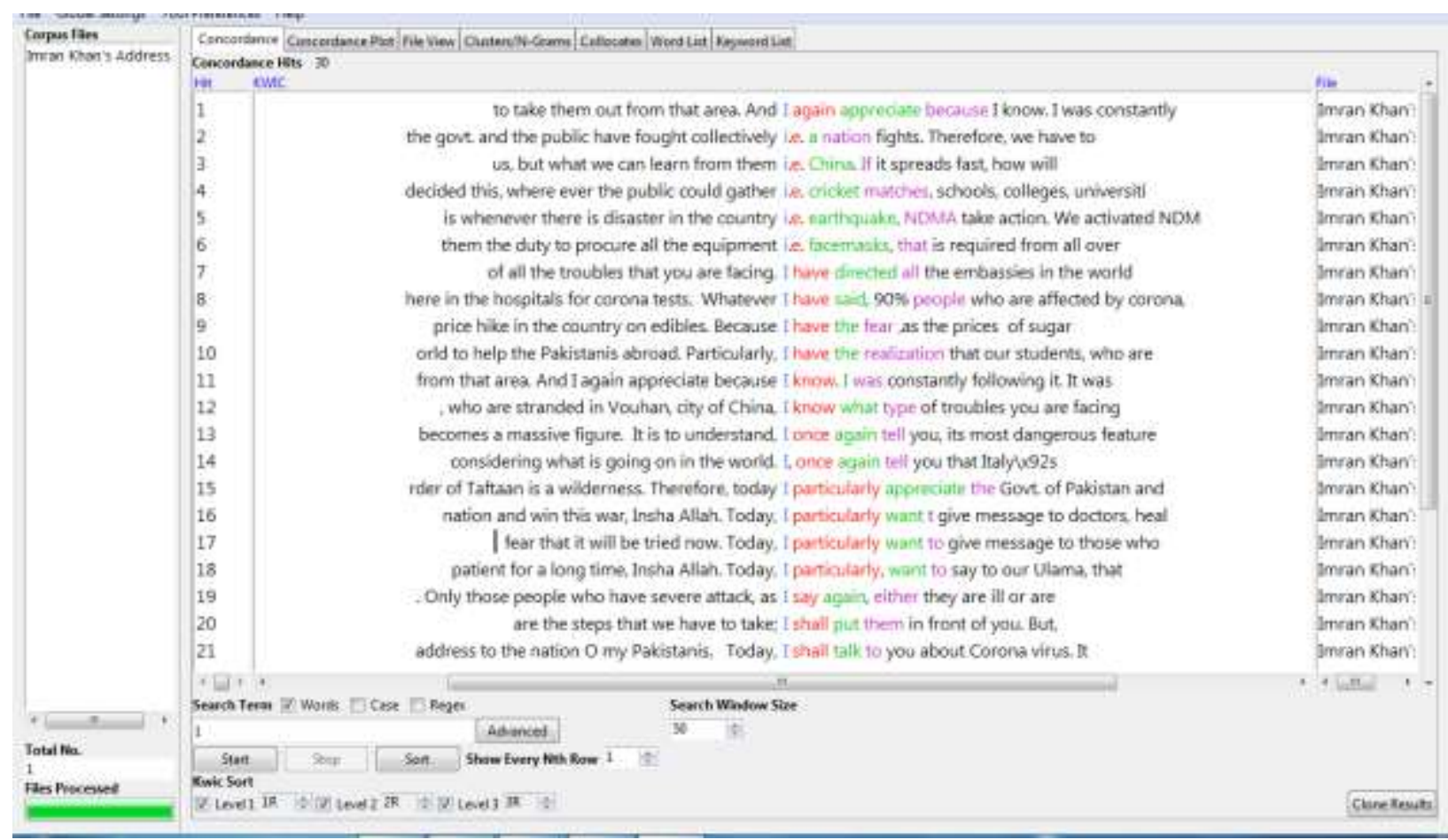

In his address to the nation, Imran Khan used the personal pronoun "I" for thirty times, having the percentage of $1.38 \%$ out of the total words. It shows that he has a strong character and high moral values. It also indicates that he takes responsibility of his actions. As the statistics drawn through concordance by using Antconc software, are an evidence that he is very much alive to the situation and leading from the front. In this way, he very well makes use of Aristotelian concept of ethos for the projection of his character. The concordances show that he has used the 
word "I" as subject of different actions. For example, "I have directed", "I have the realization", "I know", etc. He is the head of the government and a number of organizations and institutions work under his supervision. In crisis just like the pandemic of Corona virus, there is a need of prompt and quick actions. So, self belief on the part of the leader is very much important. The above mentioned data supports the idea that Imran Khan presents himself as a role model for his subordinates in particular and the masses in general by following the principal of ethos.

\section{Pathos}

It is a word of Greek language which means 'suffering' or 'experience'. The speakers and orators make use of it to evoke the emotions and feelings of the audience i.e. their fears, worries, difficulties, miseries and hopes, etc.

Prime Minister Imran khan's this address was in the background of Covid-19 pandemic which has shaken the world in every field of life. It is an infectious disease which spreads rapidly from one man to another. The concordance shows that he has mentioned the word "Corona" sixteen times in his address. He has used this word again and again to make the people conscious of how dangerous this virus is. In this way, he, knowingly or unknowingly, makes well use of "Pathos", one of Aristotle's persuasive devices.

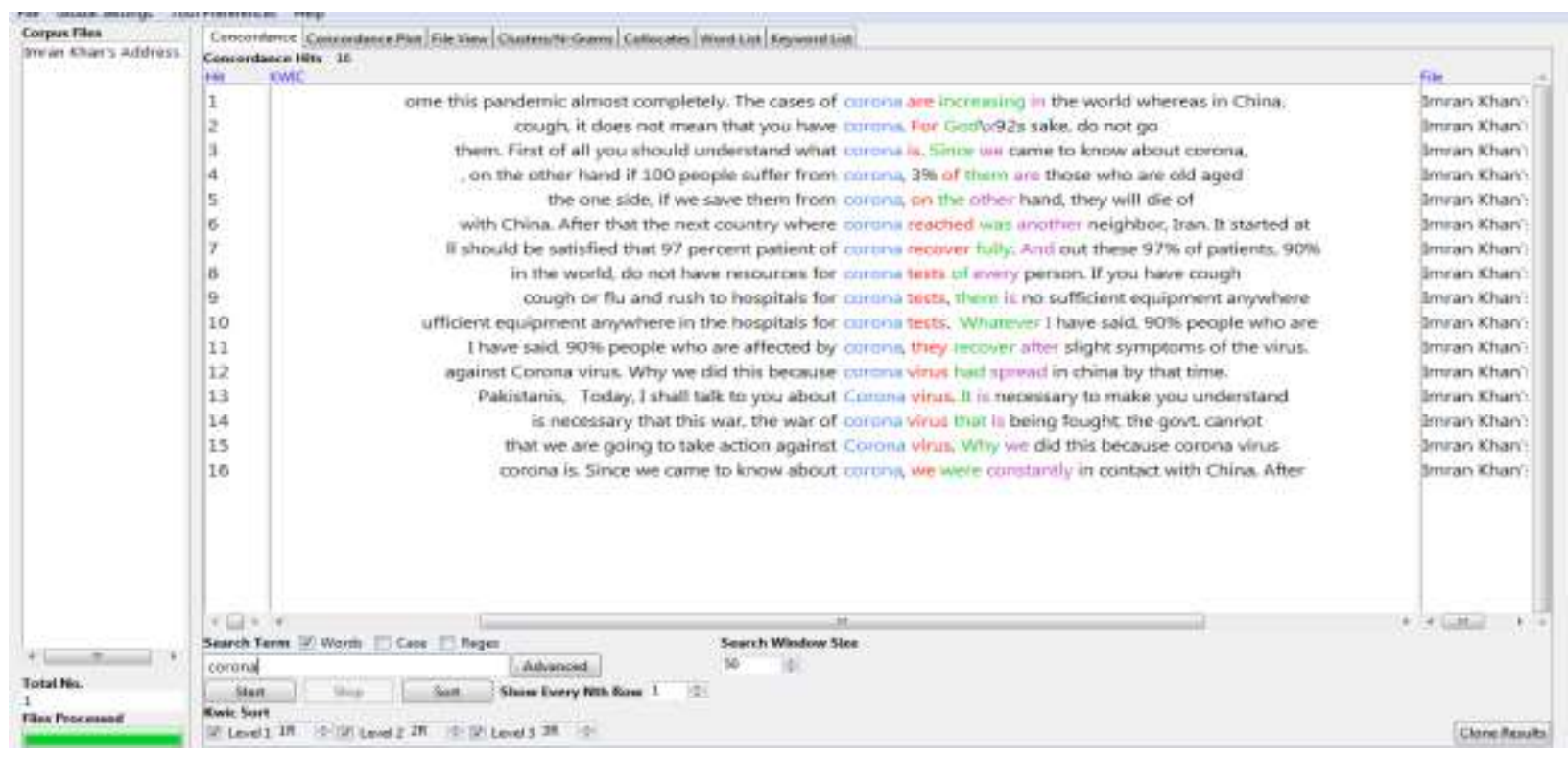




\section{Logos}

It is a Greek word which means 'a word' or 'reason'. By following logos, the speaker makes an appeal to the intellect and mind of the listeners with the help of facts and figures. Analysis of Khan's address shows that he has made an extensive use of statistics and numerical data. As for example, the following quoted text is a proof of this argument.

“And out these $97 \%$ of patients, $90 \%$ suffer from its mild attack such as flu ordinary cough. 4 to $5 \%$ patients have to go to hospital. But as you see, it is accelerating world wid. Until now it has reached 19000000 cases. When 4 or $5 \%$ percent out of such a number come in a country, it becomes a massive figure".

This text shows that he does not give sweeping statements rather he talks with the help of numerical data which appeals to the minds and intellect of the people. He argues logically and rationally which proves that he has the ability to convince the people by using the rhetorical technique of "logos". Other examples of logos can also be quoted as, "We have screened 9 lack people till now". "About $25 \%$ of our people are in acute poverty".

\section{Rhetorical Questions}

Questions are normally asked to seek information but rhetorical questions are rather asked to provide information. Rhetorical questions actually demand a mental response from the audience in the form of their acceptance of the answer conveyed to them by the addressor. A question presented by the speaker as a challenge to communicate his resolve to its hidden answer, for the sake of evoking mental acceptance of the audience as a valid one (Ilie, 1994: 128). Different language users use rhetorical questions for their communicative effective effectiveness in different situations. The most salient feature of RQs is that they are not asked to get a clear answer. In most of the situations, these questions have the answer within them that is already understood not only by the addressor but also by the listeners (Sadock, 1974; Han, 2002). 
UNIVERSITY OF CHITRAL JOURNAL OF LINGUISTICS AND LITERATURE

VOL. 4 | ISSUE II | JULY - DEC | 2020

ISSN (E): 2663-1512, ISSN (P): 2617-3611

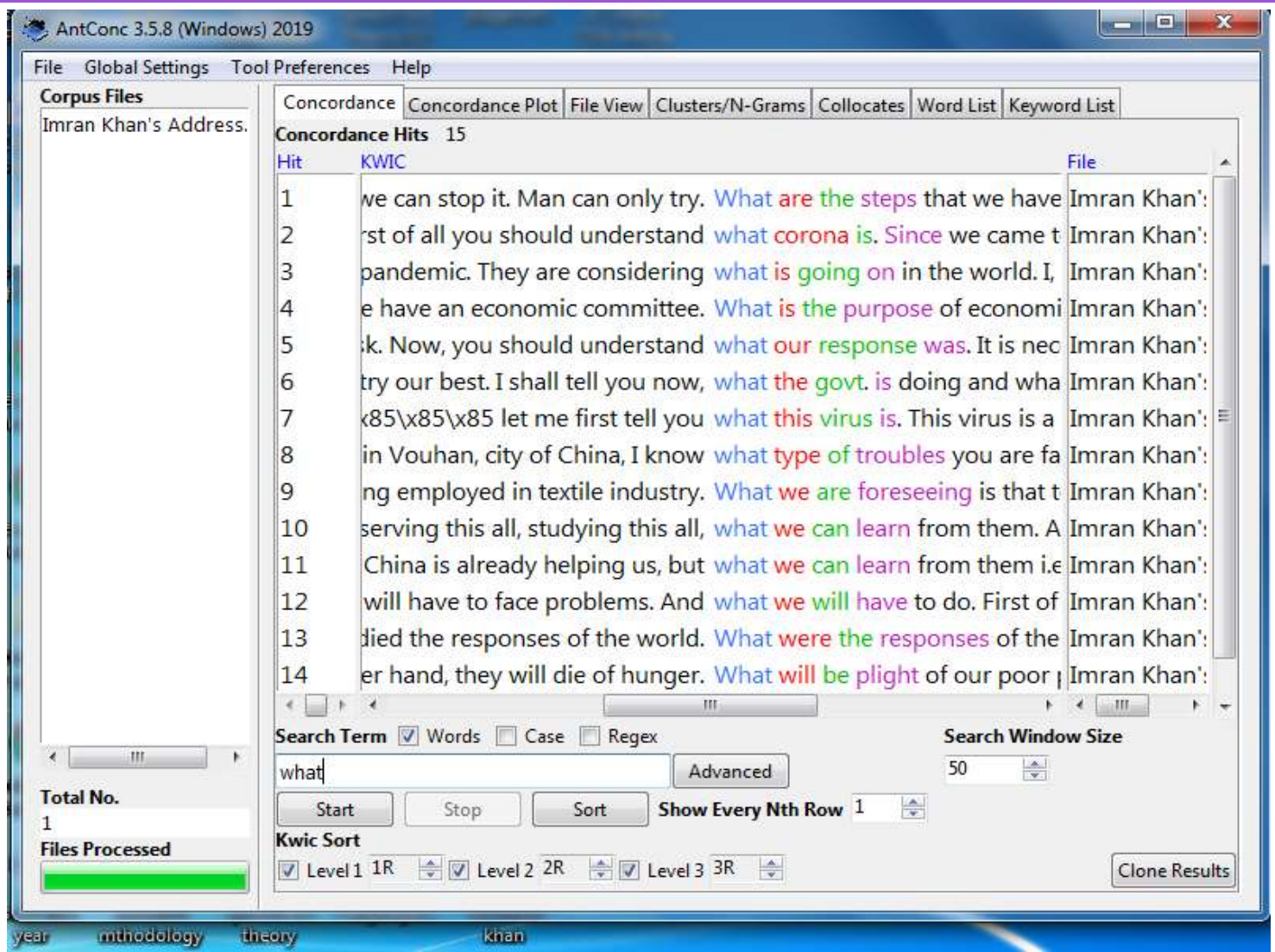

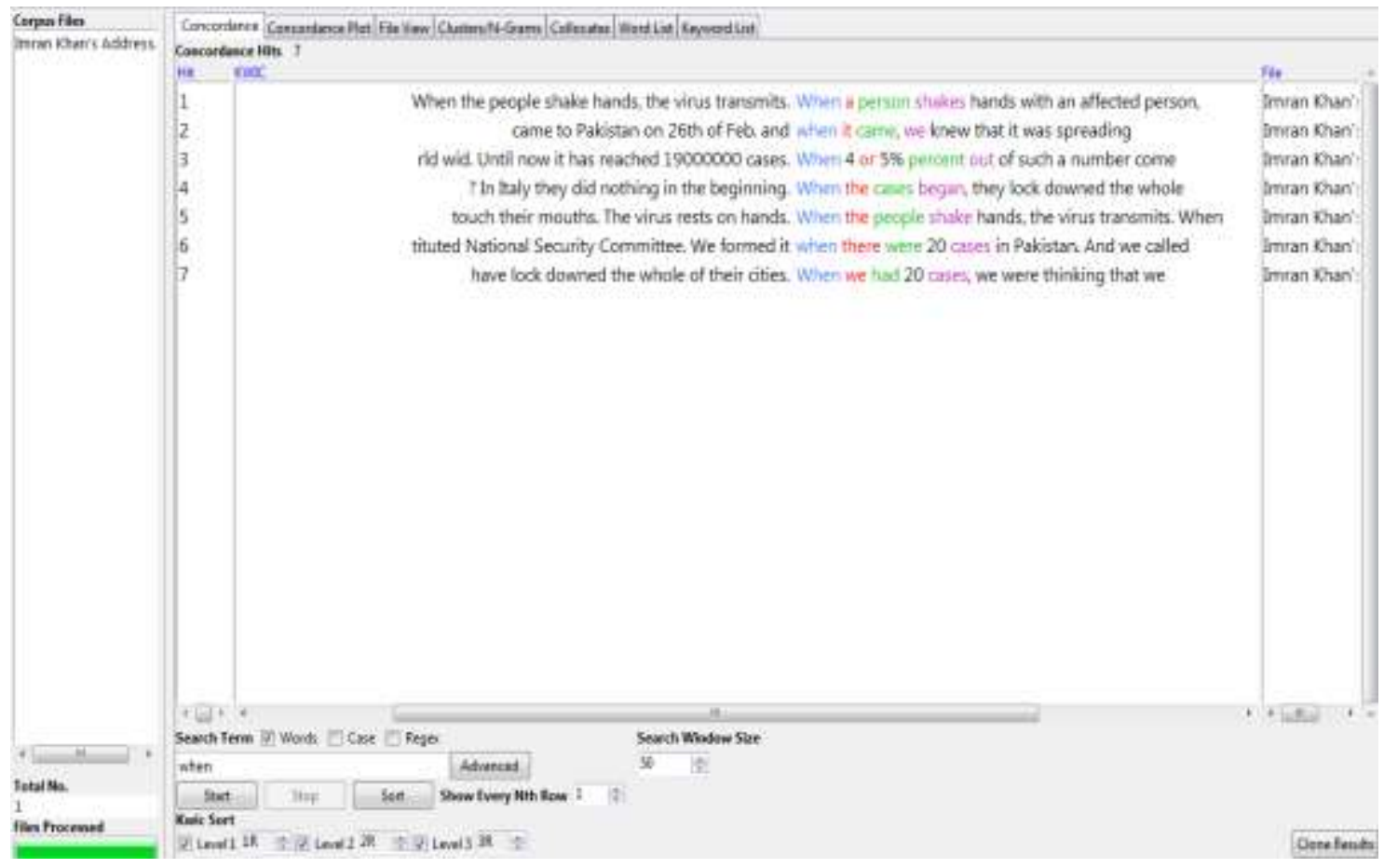


UNIVERSITY OF CHITRAL JOURNAL OF LINGUISTICS AND LITERATURE

VOL. 4 | ISSUE II | JULY - DEC | 2020

ISSN (E): 2663-1512, ISSN (P): 2617-3611
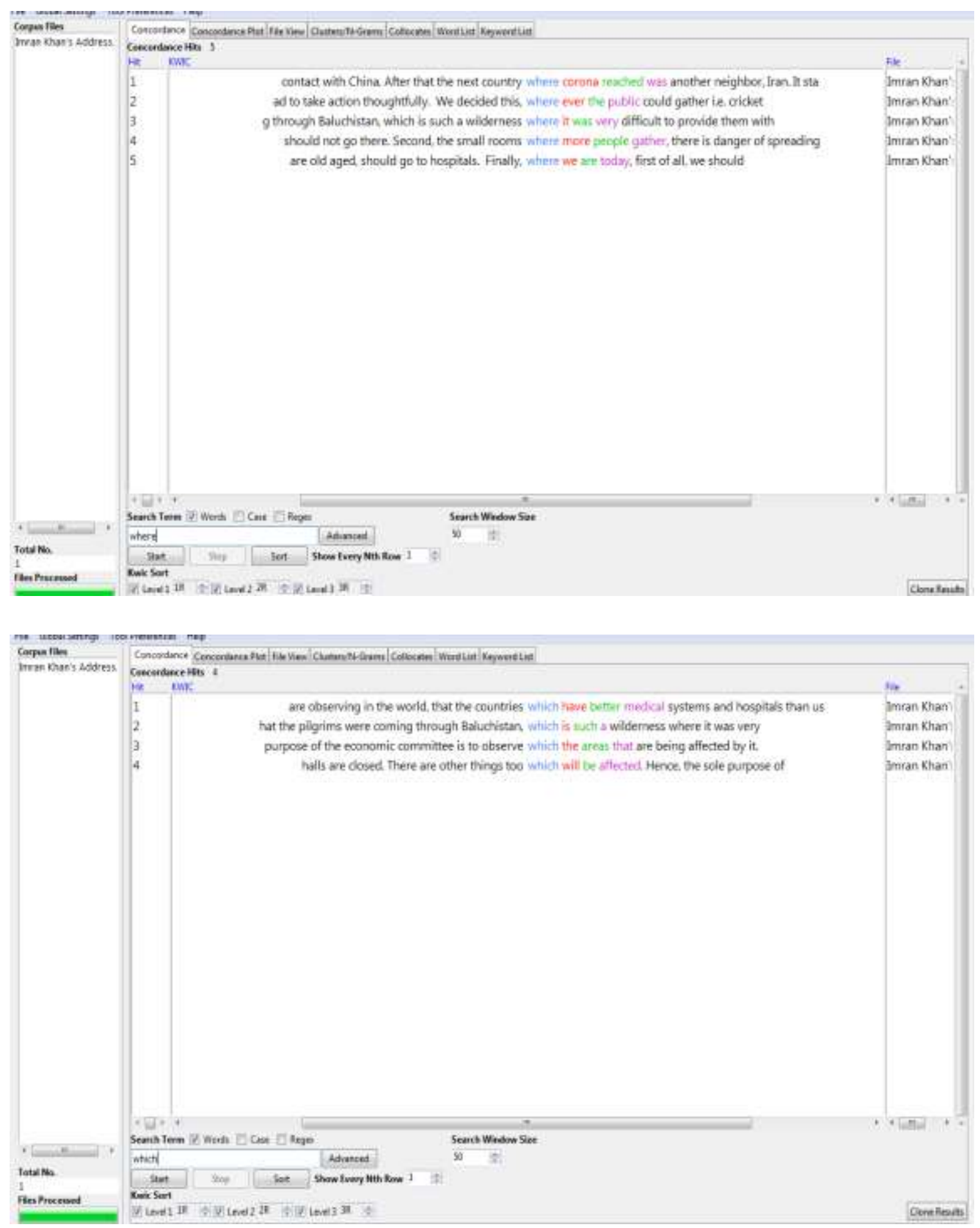
UNIVERSITY OF CHITRAL JOURNAL OF LINGUISTICS AND LITERATURE

VOL. 4 | ISSUE II | JULY - DEC | 2020

ISSN (E): 2663-1512, ISSN (P): 2617-3611

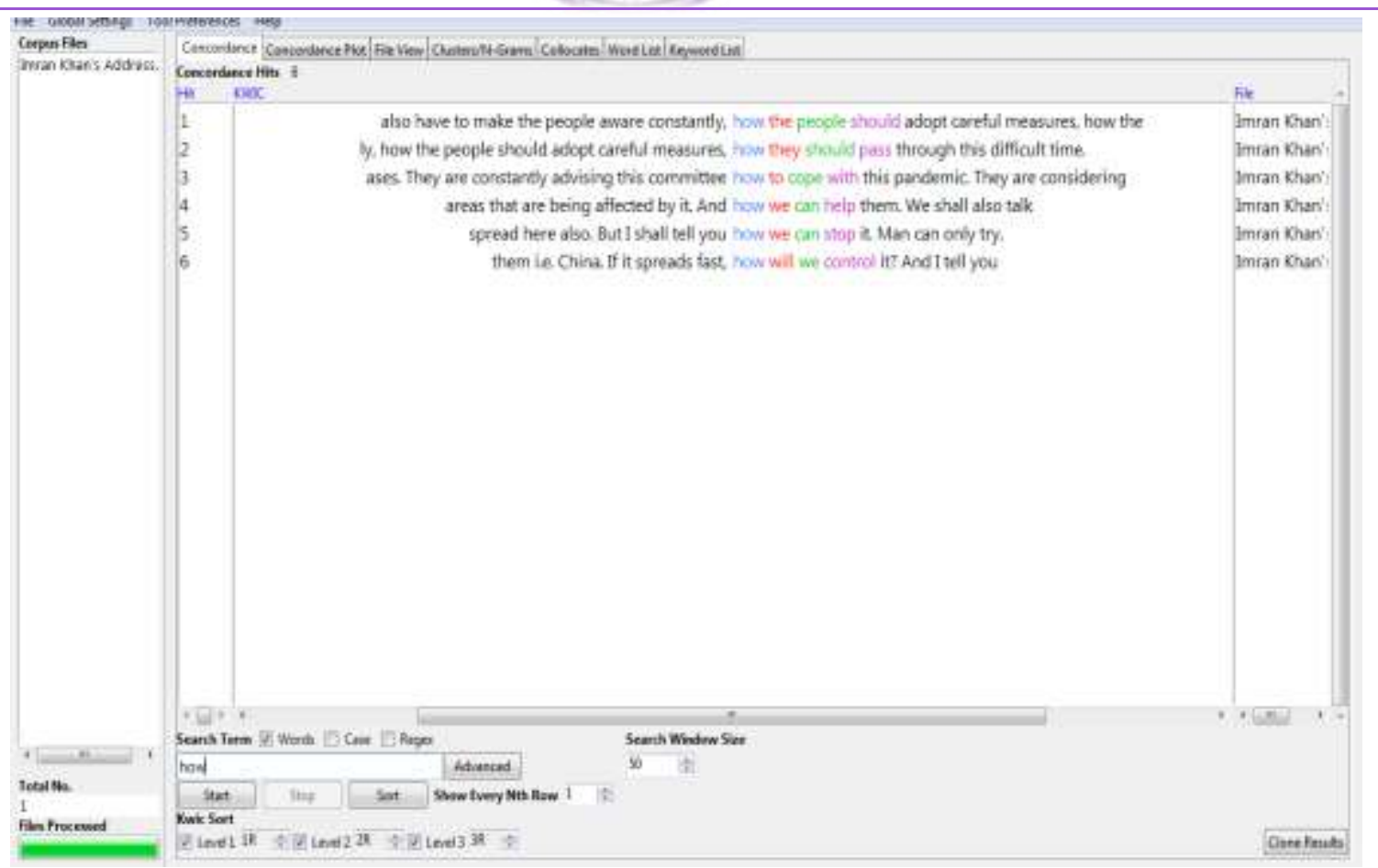

These concordances reveal that all the WH questions are rhetorical ones not in interrogative form. Imran khan makes an abundant use of rhetorical questions in order to make his arguments validated by the people.

\section{Frequency of rhetorical Questions}

$\begin{array}{lc}\text { What } & 15 \\ \text { When } & 07 \\ \text { How } & 06 \\ \text { Where } & 05 \\ \text { Which } & 04 \\ \text { Why } & 01\end{array}$

The frequency of the above words gives the clue that Khan uses them as key words in his speeches to persuade and convince the audience.

\section{Inclusive and Exclusive "we", "Our"}

Inclusive "we", is commonly used to involve the speaker, the listener and others. Exclusive "we", is used when the listeners and others are not involved (Quirk, R., Greenbaum, S., Leech, G., \& Svartvik, J. 1985, Fontaine, 2006, Uzum, B., Yazan, B. \& Ali, F. S. 2017). 
UNIVERSITY OF CHITRAL JOURNAL OF LINGUISTICS AND LITERATURE

VOL. 4 | ISSUE II | JULY - DEC | 2020

ISSN (E): 2663-1512, ISSN (P): 2617-3611

Quirk, R., Greenbaum, S., Leech, G., \& Svartvik, J. (1985). A comprehensive grammar of the English language. New York: Longman. Inclusiveness or exclusiveness of "we", is not decided within the text rather it depends on the position of the addressor and the addressee in the given context (Halliday \& Hasan, 1976).
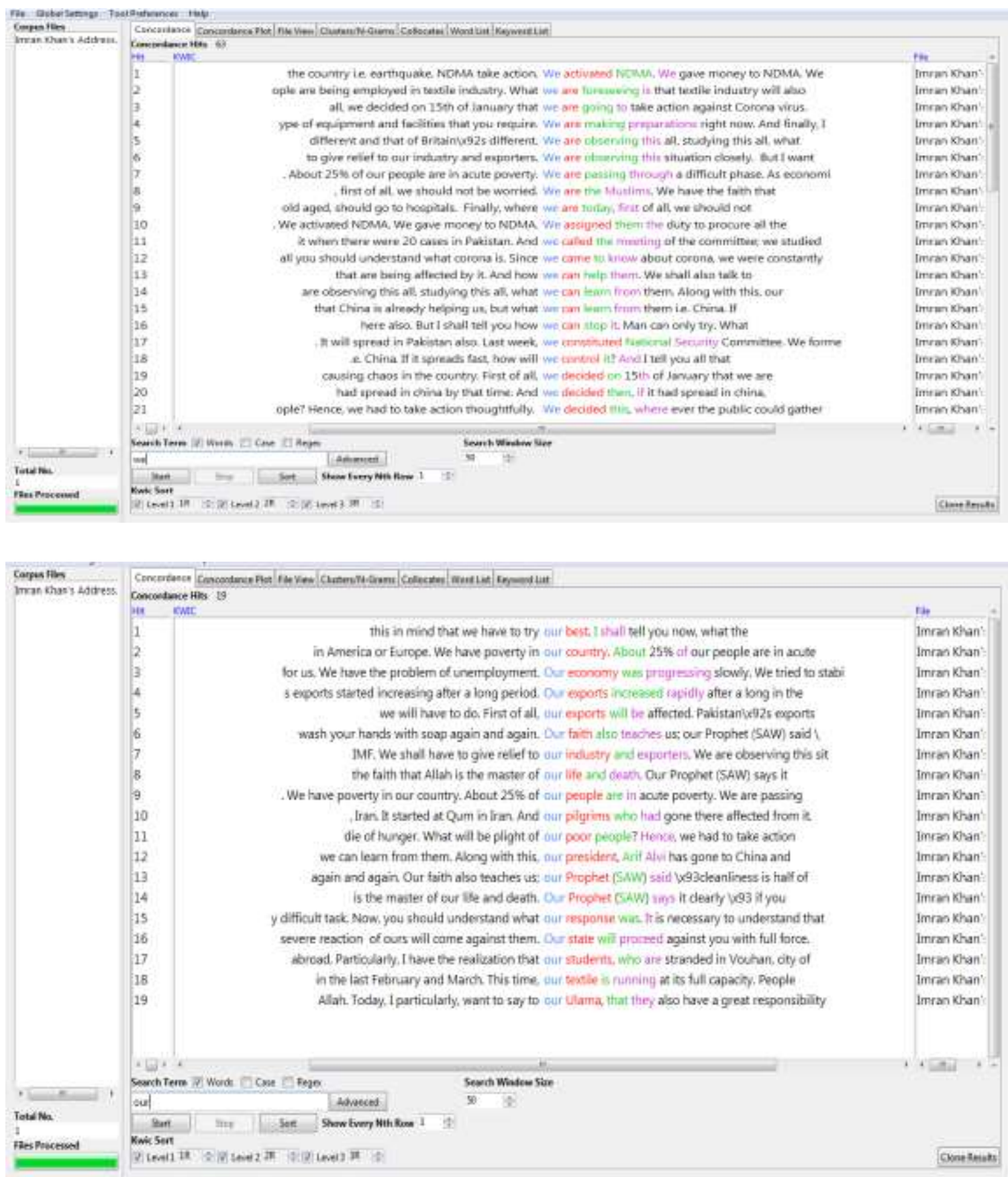

The concordances are a proof that Khan extensively use the first pronouns "we", and "our". And 
most of the time, they are used inclusively. It means that he attaches himself with the commom masses of Pakistan to give them the realization of ownership and unity. "our response", "oue students", "our state", "we are the Muslims", “we can help them", all these are examples of inclusiveness. The word "we", has the percentage of $2.86 \%$ of the total words of the address with 63 hits in the concordance. These statistics also prove that Khan amply use inclusiveness.

\section{Personal Pronouns: "I" and "you"}

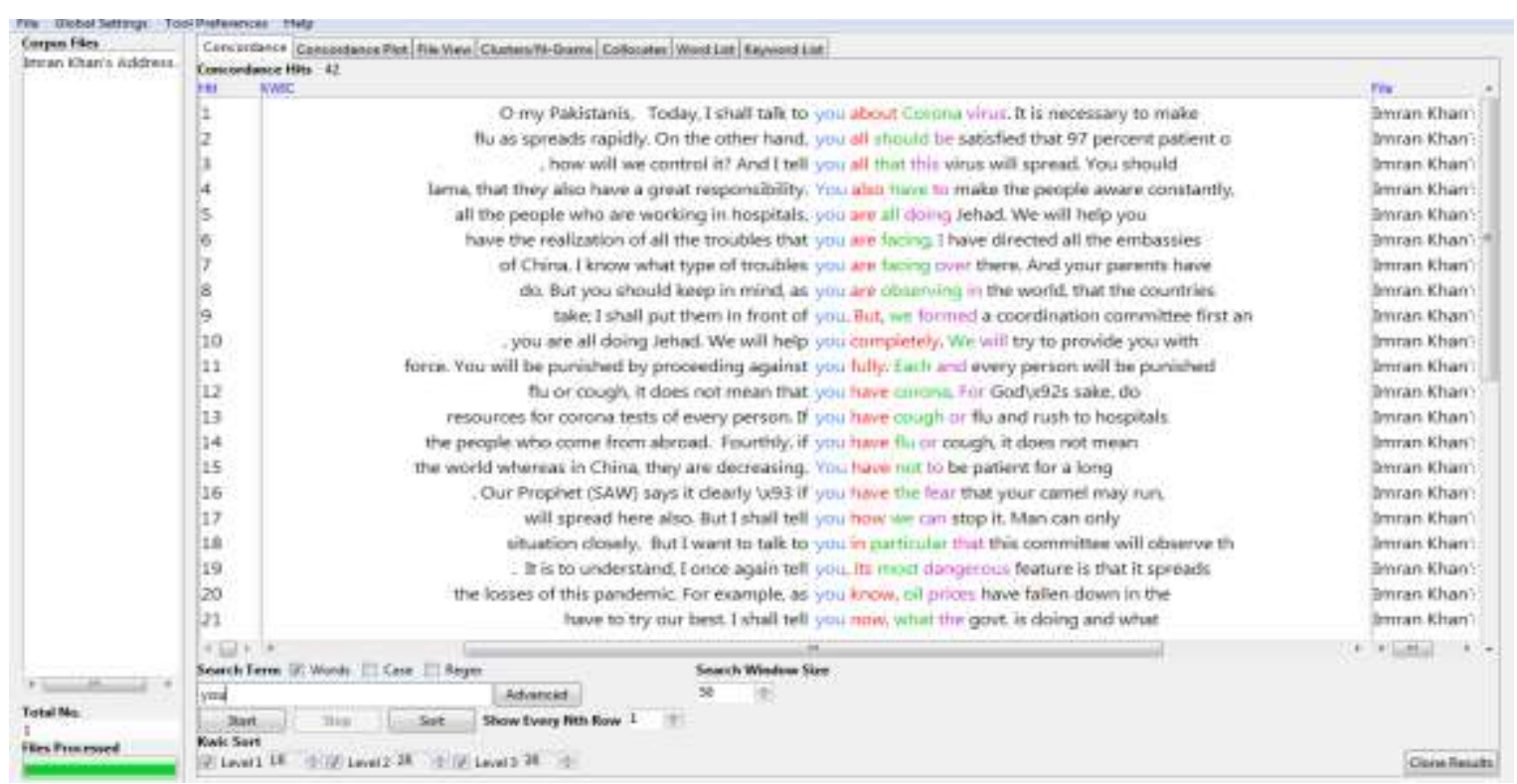

"You", is frequently used in Khan's address which is quite interesting to analyze. In Pakistani culture, "you", (aap) is generally used to give honor to the addressees. It is used to create a live interaction between the speaker and the audience. According to the concordance, the word "you" has 42 hits which is the second highest among the personal pronouns after "we". It is an evidence that Khan gives very much respect and honor to his people. A close observation of the concordances shows that "you", often occurs with "I". For example, "I shall talk to you", "I tell you", gives the idea that he wants to build a close bond with his people.

\section{The use of "They"}


UNIVERSITY OF CHITRAL JOURNAL OF LINGUISTICS AND LITERATURE
VOL. 4 | ISSUE II | JULY - DEC | 2020
ISSN (E): 2663-1512, ISSN (P): 2617-3611

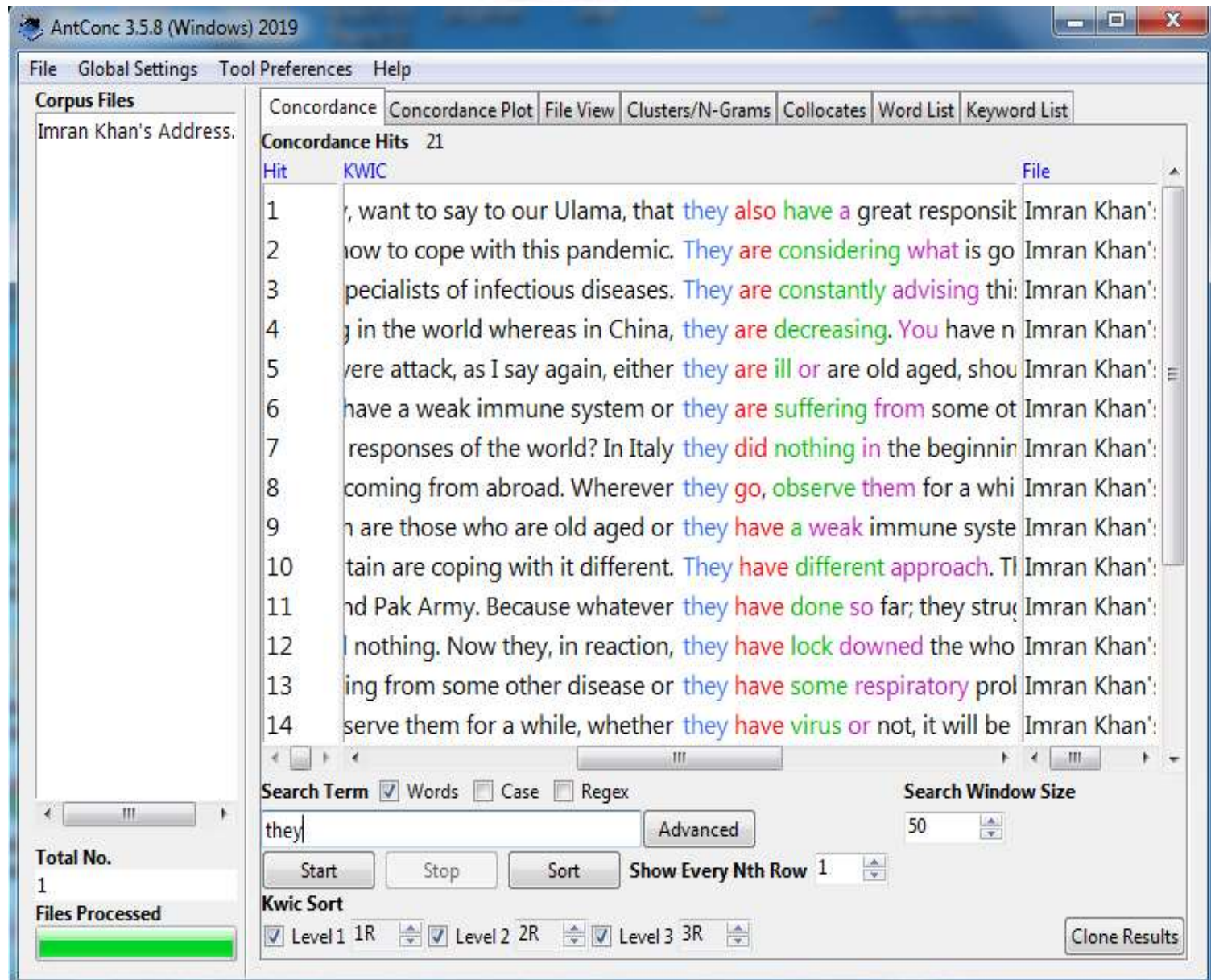

The word "they", has 21 hits in the concordance which is lesser than "we", and "you". It means 'that Khan's main focus is on establishing a close and direct relation in this time of trial. "They", refers to others. The speakers usually use this word to let down their opponents and prove them inferior to them. But the concordances show that Khan has used this word with positive connotation most of time which is the need of hour. Examples to support this point are, "they have done", "they are considering".

Analysis of Khan's use of personal pronouns throws light on the fact that he wants to establish relationship between himself and the masses in this situation of emergency. Plentiful use of "I", helps him to build a strong and active image of his character. "We", with the greatest number among the personal pronouns is the proof that he works with his government officials and other stake holders as a team. The positive connotation of "they", also indicates the gravity of situation. 


\section{Results}

There are two types of results: quantitative ( obtained through corpus soft ware), and qualitative ones (detailed elaboration) of those numerical data. Both quantitative and qualitative data show that Imran khan has utilized the Aristotelian elements of persuasion successfully to a great extent. He has made an effective use of persuasive devices ( ethos, pathos, and logos) proposed by Aristotle. The use of personal pronouns "I", "we", "you", and even "they" in positive meanings illustrate the fact that he is well aware of the severity of the situation and wants to work in collaboration with others. The data also show that he has also very well maneuvered the rhetorical tools such as use of rhetorical questions again and again, inclusiveness and exclusiveness, formal language, repetition, colloquial language and images, etc.

\section{Conclusion}

This study was based on corpus assisted analysis of Imran khan's address to the nation. The purpose of this study was to look into how well he has employed the Aristotelian elements of persuasion in the concerned address. The numerical and interpretative data are in favor of the argument that he has utilized these devices in a convincing manner. By using these tools, he has tried to prove that he is the leader of the nation and is conscious of the problems of the people.

Previous studies have worked on these aspects of Khan's speeches but only qualitatively. But this study has analyzed the data qualitatively in the light of empirical one obtained through the use of corpus software AntConc. In short, it is observed that Khan has skillfully manipulated the persuasive and rhetorical devices to be compassionate and sympathetic to the people.

\section{References}

Aazam, F., Baig, F. Z., Baig, T., Khaliq, S., Azam, A., Shamshad, S., \& Aslam, M. Z. (2019). A Critical Discourse Analysis of 'Fire and Fury: Inside the Trump White House' by Michael Wolff. InternationalJournal of English Linguistics, 9(4), 192-199. https://doi.org/10.5539/ijel.v9n4p192

Abrahamson, E. (1997). The emergence and prevalence of employee management Academy of Management Journal, 40, 491-533. 
UNIVERSITY OF CHITRAL JOURNAL OF LINGUISTICS AND LITERATURE

VOL. 4 | ISSUE II | JULY - DEC | 2020

Alghamdi, N. A., \& Rand, A. (2019). Cross-Cultural Linguistic Analysis of Persuasive Techniques in Shark Tank. International Journal of English Language Education, 7(2), 82107. https://doi.org/10.5296/ijele.v7i2.15416.

Amjad, M. (2019). A Discourse Analysis of Canadian PM's Speech after New Zealand Christchurch Mosque Shootings. University Of Chitral Journal Of Linguistics \& Literature, 2(II), 1-14. doi:10.33195/j1l.v2iII.166

Aristotle. (1984). Rhetoric (R. Roberts, Trans.). New York: The Modern Library.

Bahaziq, A. (2016). Cohesive Devices in Written Discourse: A Discourse Analysis of a. English Langauge Teaching, 8.

Baig, F. Z., Aslam, M. Z., Yaseen, T., Ahmad, H. S., Murtaza, M., \& Abbas, M. J. (2020). Practicing Language Therapy for Effective Simultaneous Bilingualism: Case Studies. International Journal of English Linguistics, 10(1), 230-240. https://doi.org/10.5539/ijel.v10n1p230.

Baig, F. Z., Umer, S., Aslam, M. Z., Razaq, M. S., Khan, S. \& Ahmad, Ahmed, T. (2020). Humor as Monotony Breaker in Funny Ads: A Multi-Modal Discourse Analysis of Ads of Pakistani Ufone \& Jazz Cellular Companies. International Journal of English Linguistics, 10(1), 69-80. https://doi.org/10.5539/ijel.v10n1p69.

Baig, F. Z., Yousaf, W., Aazam, F., Shamshad, S., Fida, I., \& Aslam, M. Z. (2019). Power, Ideology and Identity in Digital Literacy: A Sociolinguistic Study. International Journal of English Linguistics, 9(2), 252-264. https://doi.org/10.5539/ijel.v9n4p252

Bass, B. M. (1996). A new paradigm of leadership: An inquiry into transformational

Beasley, V. (2004). You, the people: American national identity in presidential rhetoric.

Bitzer, L. (1968). The rhetorical situation. Philosophy \& Rhetoric, 1, 1-14. College Station: Texas A\&M University Press.

Boris Fausto, S. F. (2014). A Concise History of Brazil Second Edition. United States of America: Cambridge University Press.

Chiu, Y.-h. (n.d.). The L2 Acquisition of the Coordinating Conjunction "and" in Taiwanese 
Learners' Interlanguage at College Level . Asian EFL Journal, 20.

Choudhary, A. k. (2017). A Corpus-based Study of Conjunctions in Mohsin Hamid novels. International Journal of Scientific and Research Publications, 4.

Cleary, B. P. (2012). But and For, Yet and Nor: What Is a Conjunction? Millibook Press.

Editors, B. (2020). Paulo Coelho Biography. The Biography.com website.

Erisen, C., \& Villalobos, J. D. (2014). Exploring the invocation of emotion in presidential speeches. Contemporary Politics, 20 (4), 469-488.Edlund, J \& Pomona, C. P. Ethos, Logos, Pathos: ThreeWays to Persuade http://web.calstatela.edu/faculty/jgarret/3waypers.htm

Ethos and Personality Stance. Study Guide pages 29-45

Golden, James L., Goodwin F., (1983) Berquist,and William E. Coleman, TheB.betoricof Westem Thought (Dubuque,10:KendallPublishingCo., [19762).

Halliday, M. A., \& Hasan, R. (1976). Cohesion in. English, Longman, London.

Hamidi, H., \& Mirzaee, S. (2012). Critical Discourse Analysis and Fairclough's Model. International Electronic Journal for the Teachers of English, 2(5), 182-190. Retrieved January 21, 2020, from https://www.academia.edu/2645766/Critical_Discourse_Analysis_and_Faircloughs_Mod el-_Mirzaee_and_Hamidi_2012_

Hasan, M. H. (2013). Cohesion in English. Newyork: Longman Group Limited.

Higgins, C., \& Walker, R. (2012). Ethos, logos, pathos: Strategies of persuasion in social/environmental reports. Accounting Forum, 36, 194-208.

Higgins, C., \& Walker, R. (2012). Ethos, logos, pathos: Strategies of persuasion in social/environmental reports. Accounting Forum, 36, 194-208.

Horvath, J. (2009). Critical discourse analysis of Osama's political discourse (pp. 22-23). Language, Literature, and Culture in a Changing Transatlantic World International Conference Proceedings, University Library of Prešov University. Retrieved January 28, 
2020, from

http://www.cs.columbia.edu/ sbenus/Teaching/APTD/Horvath_CDO_Obama.pdf.

Ilie, C., (1994) What Else Can I Tell You? A Pragmatic Study of English Rhetorical Questions as Discursive and Argumentative Acts. Stockholm: Almqvist \& Wiksell International. Sadock, Jerrold M. (1974) Toward a Linguistic Theory of Speech Acts. New York: Academic Press.in the creation of competitive advantage. Management Communication.

Ilona Leki, A. C. (2008). A Synthesis of Research on Second Language Writing in English. UK: Routledge.

Khalil, U., Islam, M., Chattha, S. A., \& Qazalbash, F. (2017). Persuasion and Political Discourse: A Critical Discourse Analysis of Imran Khan's Election Speech. Pakistan Vision, 18(2), 193-210. https://doi.org/10.1080/17405904.2019.1665079.

Ko, D. H. (2015). Political persuasion: Adopting Aristotelian rhetoric in public policy debate strategies. International Journal of Humanities and Social Science, 5(10), 114-123. $\begin{array}{llll}\text { Retrieved } \quad \text { February 2020, } & \text { 1, }\end{array}$ fromhttp://www.ijhssnet.com/journals/Vol_5_No_10_October_2015/12.pdf

leadership. Washington, DC: U.S. Army Research Institute for the Behavioral

Lin, J. L. (2000). 語藝批評:理論與實務（Rhetoric critics: Theory and practice ） Taipei: WuNan Book Inc.Management Executive, 5, 31-45.

Norali, N., \& Rezaei, S. (2016). Language and power: The use of persuasive techniques in Iran and U.S. President Speeches. Journal of Language Teaching and Research, 7(6), 12031209.https://doi.org/10.17507/jltr.0706.19.Nelson, T. E. (2004).Policy goals, public rhetoric, and political attitudes. Journal of Politics, 66, 581-605.

Nurrosyidah, H. Y. (2016). Persuasive Strategies in Joko Widodo's Political Speeches. Master's thesis, Maulana Malik Ibrahim State Islamic University Malang. Retrieved January 12, 2020 ,

from

https://pdfs.semanticscholar.org/4c25/0e3206390842ea8a3f2d57d8afd69a50da5f.pdf

Partington, Alan / Duguid, Alison / Taylor, Charlotte 2013. Patterns and Meanings in Discourse: 
UNIVERSITY OF CHITRAL JOURNAL OF LINGUISTICS AND LITERATURE

VOL. 4 | ISSUE II | JULY - DEC | 2020

ISSN (E): 2663-1512, ISSN (P): 2617-3611

Theory and Practice in Corpus-Assisted Discourse Studies (CADS). Amsterdam/Philadelphia: John BenjaminsPublishing.Koteyko, Nelya 2014. Language and Politics in Post-Soviet Russia.London: Palgrave Macmillan.

Peng, H. E. (2007). 政治傳播:理論與實務 ( Political communication: Theory and practice). Taipei: Feng Yun Forum Inc.

Putnam, Linda L., and Cheney, G., (1985)"OrganizationalCommunication:Historical Development and Future Directions,"ingommun.ic:ation in the Ikgmti.eth Century, ThomasBenson, ed.(Carbondale, ILL:Southern Illinois University Press,),pp.130156.Quarterly, 10, 145-179.

Qadar, A. (2019). British Council's English for Academic Purposes: A Critical Analysis of the Coursebook Taught at Pakistani Universities. University Of Chitral Journal Of Linguistics \& Literature, 3(I), 20-28. doi:10.33195/j1l.v3iI.176

Redding, Charles W., (1985). "Stumbling Towardidentity:The Emergence of OrganizationalCommunicationasaFieldofStudy,"inOrganiztionalcgmm911.t.i.P9.1Ttagi.ti onalThemesF;AsIdII!v4Pirections,Rc, bertD.MLPheeand PhillipK.Tompkins,eds.(Beverly Hills, CA:Sage,), pp. 179-210. rhetorics: The effects of long waves, labor unions, and turnover, 1875 to 1992 .

Sharififar, Massoud / Rahimi, Elahe 2015. Critical Discourse Analysis of Political Speeches: A Case Study of Obama's and Rouhani's Speeches at UN. Theory and Practice in Language Studies 5, 99- 110, 343-349.

Siiner, Maarja 2018. Corpus Assisted Discourse Analysis of Presentationsof 'Dementia', 'Aging' and 'Elderly Immigrants' in Norwegian

Sillince, J. A. A. (2006). Resources and organizational identities: The role of rhetoric status in a complex change management program. Group \& Organization

Smircich, L., \& Morgan, G. (1982). Leadership: The management of meaning. Journal of Applied Behavioral Science, 18, 257-273.

Stephen, D. R. (2017). Writing Analytically. United States of America: ebooks. 
Triadafilopoulos, T. (1999). Politics, speech, and the art of persuasion: Toward an Aristotelian conception of the public sphere. The Journal of Politics, 61(3), 741-757.

Unubi, A. S. (2019). Conjunctions in English: Meaning, Types and Uses. International Journal of Social Science and Humanities Research, 13.

Van Dijk, T. A. (1997). What is political discourse analysis. Belgian Journal of Linguistics, 11(1), 11-52.https://doi.org/10.1075/bj1.11.03dij.

Van Dijk, Teun A. (1998). Editorial: Discourse and Ideology. Discourse \& Society 9/3, 307-308.

Young, D. J. (n.d.). The Mechanics of Writing. United States.

\begin{tabular}{|l|l|l|}
\hline (C) 2020 by the author. Licensee University of Chitral, \\
Journal of Linguistics \& Literature, Pakistan. This article is an \\
open access article distributed under the terms and conditions of \\
the Creative Commons Attribution (CC BY) \\
(http://creativecommons.org/licenses/by/4.0/).
\end{tabular}

